\title{
Soil Aquifer Treatment as a Tool for Sustainable Groundwater Use in Hanoi/Vietnam
}

\author{
Axel René Fischer ${ }^{1}$, Catalin Stefan ${ }^{1}$, Kay Silabetzschky ${ }^{1}$, Peter Werner $^{1}$, Bui Hoc ${ }^{2}$ \\ ${ }^{1}$ Institute of Waste Management and Contaminated Site Treatment, Technische Universität Dresden, Pirna, Germany; ${ }^{2}$ Vietnam As- \\ sociation of Hydrogeology, Hanoi, Vietnam. \\ Email: axel_rene.fischer@tu-dresden.de
}

Received June $3^{\text {rd }}, 2011$; revised July 29 ${ }^{\text {th }}, 2011$; accepted August $31^{\text {th }}, 2011$.

\begin{abstract}
Due to the subtropical climate the average annual precipitation in Vietnam is high. Nevertheless it is observed that groundwater levels in the capital Hanoi have decreased dramatically. As a consequence more and more settlements of buildings have been registered since the beginning of the new millennium. Reason for this tremendous impact is the increasing demand of areas and the extensive surface sealing in the course of the industrial development. This paper describes the "state of the art" and the development of sustainable solutions to maintain and even increase the declined groundwater levels in Hanoi.
\end{abstract}

Keywords: Groundwater Withdrawal, Groundwater Recharge, Land Subsidence, Settlements

\section{Introduction}

Water resources in Vietnam are difficult to manage due to the high levels of precipitations. During the last decade groundwater was used intensively for different purposes due to the growing demands of a fast developing nation. After the reunion of North and South Vietnam in 1975 , the country expanded more and more to a leader under the crop and vegetable exporting nations. In the course of this development groundwater extraction became an important factor e.g. for the irrigation of coffee plants. For example Dak Lak province is estimated to produce 405,000 t coffee per year for the world market [1].

Due to the development of the infrastructure in fast growing cities settlements of buildings by groundwater drawdown are a worldwide and also well known phenomenon [2,3]. At first view this should be excludable in Vietnam because heavy rainfalls occur at least in the summer time. However, an important degree for the "water stress" of a country is not the overall rainfall but rather the ratio of withdrawal to renewable water resources. Although only weak water stress is generally present in the South Eastern Asian region (ca. 4.8\%), the ratio in Vietnam (about $17 \%$ - 18\%) is comparable to Europe [4]. Additionally, the majority of rain fall is supplied mainly during the rainy season. Therefore, groundwater levels are fluctuating over the year to a high extent. The enormous grow of industry in the capital of Vietnam has influenced its water balance. Hanoi's population is estimated to reach five million inhabitants by 2015 [5]. Groundwater levels in Hanoi have decreased during the last years resulting in manifold detriments e.g. settlements of buildings [6] and elevated arsenic levels by vertical drawdown of water from other groundwater stories [7].

In the course of this development efforts are made to find sustainable solutions for the megacity Hanoi [8]. Hanoi will quickly develop in the next years which offers also a chance to find a strategy with sustainable solutions for a well balanced water economy which could be also applied to similar cases.

\section{State of the Art}

\subsection{Water Demand and Following Problems}

The capital Hanoi is located in northern part of Vietnam. There are five rivers and more than 100 lakes and ponds within the city. Red river (northwest and south) and Duong river (northeast) are the main streams of Hanoi which serve also as receiving waters (Figure 1).

Beside some small "septic tanks" which have been installed for the wastewater of private houses Hanoi has no sewerage system i.e. nearly all industrial and private wastewaters are directly infiltrated into a recipient e.g. the Red River. Groundwater levels are changing from 


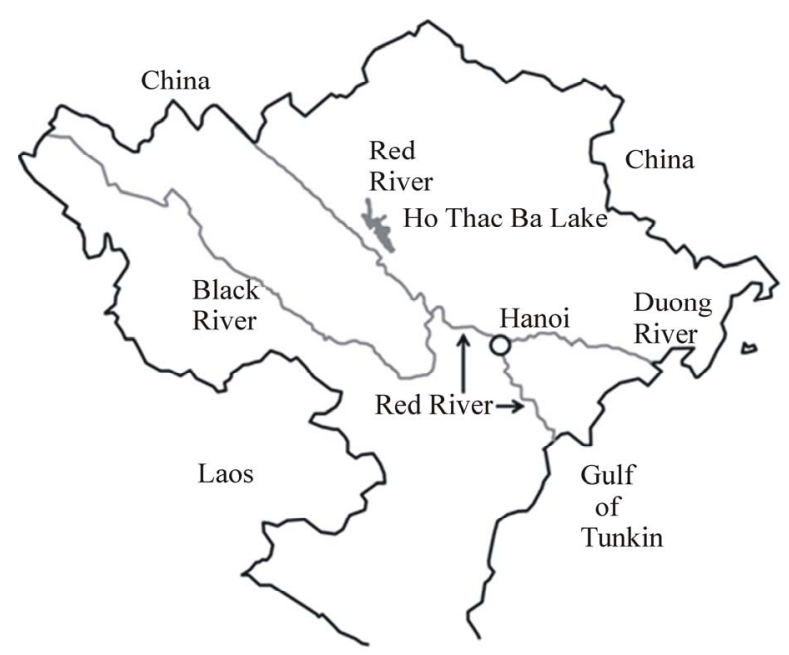

Figure 1. Map of Northern Vietnam.

month to month to a high extent due to the heavy rainfalls.

Most of the rainwater occurs in hot season but more than the half of this amount is lost by immediate evaporation.

The wastewater is transported through a joint drainage and sewage system to the water bodies throughout the city [9]. Figure 2 shows the groundwater levels for wells in some districts of Hanoi in 1993, 2005 and the supposed levels in 2020, respectively [10,11]. A decrease of the groundwater levels of up to $17 \mathrm{~m}$ in 15 years can be observed. The intensity of the loss is not uniformly and depends on the intensity of the groundwater usage in the related areas.

Overall groundwater usage in Hanoi has increased during the last years. In an approximately $5 \mathrm{~km}$ wide zone along the Red River, the Holocene and Pleistocene aquifers are mainly recharged from the river, with the more distant Pleistocene aquifer predominantly recharged by vertical percolation from the Holocene aquifer [12]. Near the beginning of Duong River the subsurface is composed of unconsolidated sediments of Pleistocene and Holocene age as described in Table 1. It is known that some soil layers consist of high permeable sand fractions which can even connect the different aquifers [13]. The analysis of vertical soil profiles in the above region reveals a high un-homogeneity of subsurface layers caused by the long term development of the area and by the steady actions of the two rivers (sediments deposition, changes of flow paths etc). A high amount of arsenic is mobilized every year from the Holocene sand and discharged into the Red River [14].

The rapid urbanization caused an impervious pavement of areas. It is known that soil and especially coarse clay swells to a high extent if it imbibes high amounts of
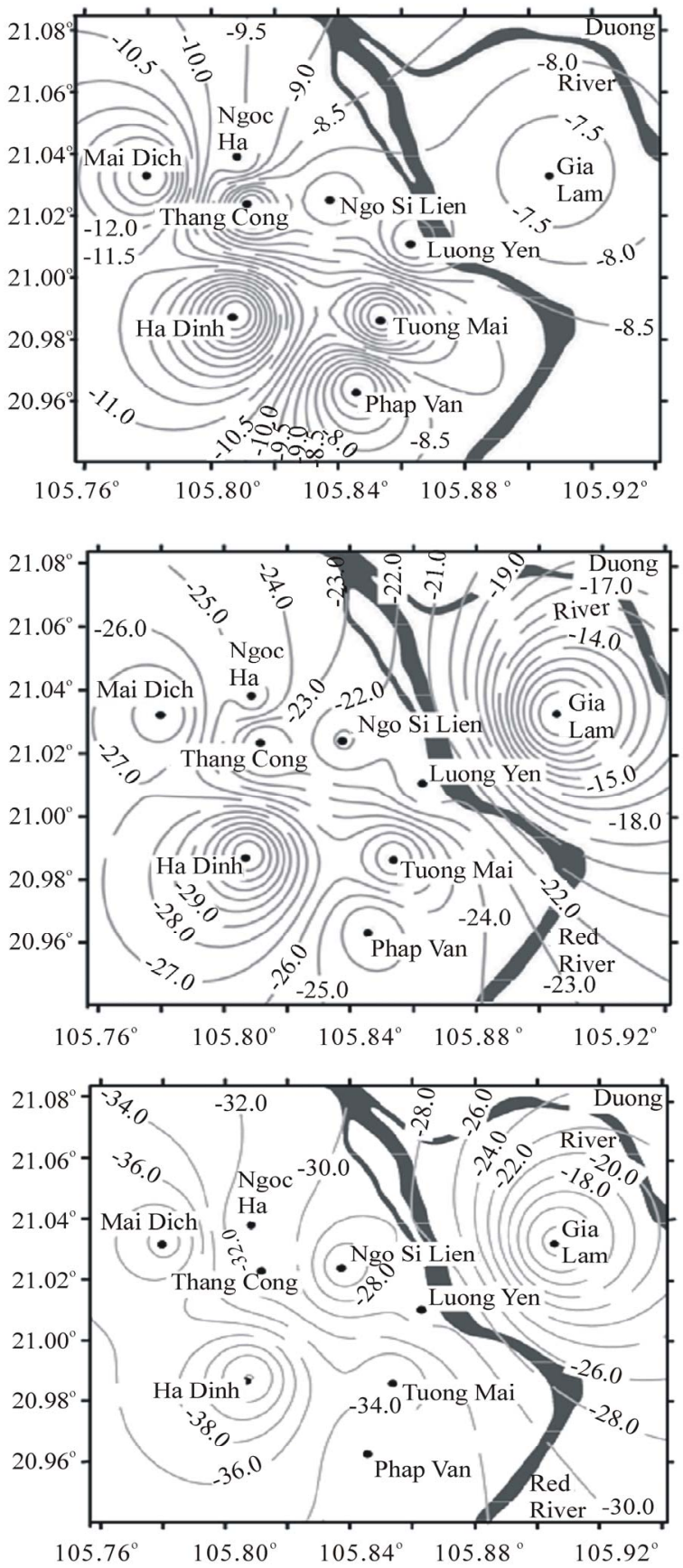

Figure 2. Groundwater levels in some districts of Hanoi in 1993 (top), 2005 (middle), and 2020 (bottom) (prognosis based on data from 1993 and 2005).

water [15]. Therefore, withdrawal of water in conjunction with coverage of possible influents led to a tremendous impact of the geohydrology of Hanoi which has influenced the static conditions of the soil. Figure 3 shows the surface settlements for 10 different districts in Hanoi from 2003 to the end of 2006 [16].

Based on monthly monitoring data on groundwater 
Table 1. Hydrogeological stratigraphy of Hanoi between Red River and Duong River (near fork of both rivers, [11]).

\begin{tabular}{ccl}
\hline Layer from top & \multicolumn{1}{c}{ Layers } & \multicolumn{1}{c}{ Depth $(\mathrm{m})$} \\
\hline 1 & Unconfined Holocene aquifer & $2-12$ (mean: 6.8) \\
2 & Pleistocen-Holocene & $1-23$ (mean: 10.2) \\
3 & Semi-confined upper Pleistocene aquifer & $2-28.3$ (mean: 14.9) \\
4 & Pleistocen impermeable layer & $0-19$ (mean: 6.4) \\
5 & Confined mid-lower Pleistocene aquifer & $21.5-47$ (mean: 32) \\
6 & Complex water stored Neogene system & \\
\hline
\end{tabular}

Date (Jan 2003 - Nov 2006)

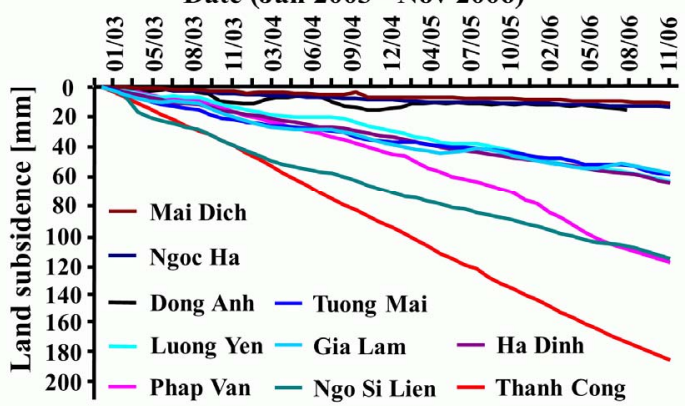

Figure 3. Surface settlements in 10 districts of Hanoi (HCA, 2007).

level and land subsidence, the qualitative assessment of land subsidence in Hanoi area has shown that:

- The land subsidence has been occurring at all monitoring stations

- Average land subsidence rate was nearly constant over the whole year

- The biggest yearly subsidence rate has been observed in Thanh Cong (46 mm/year)

Due to these facts a further intensive use of groundwater is only advisable under the precondition that sustainable methods for groundwater recharge would be established.

\subsection{Geological Conditions and Water Balance in Hanoi}

Hanoi metropolitan area relies mainly on groundwater for its water supply. Due to the local geogenic conditions some groundwater stories contain arsenic. The concentrations can differ even in a small region [17]. The people are protected from the hazardous influence of this toxic compound by the usage of groundwater levels which do not contain remarkable amounts.

The detailed analysis of vertical soil profiles has shown a high un-homogeneity of subsurface layers caused by the long term development of the area and by the steady actions of the two main rivers (sediments deposition, changes of flow paths etc).

The existing intermediary impermeable layers situated in between groundwater aquifers have a sporadic and inconsistent character and appear in forms of lenses and very thin layers. A calculation of groundwater replenishment shows that only $5 \%$ of the annual precipitation reaches the aquifer (Figure 4). Main loss is the evaporation fraction $(932 \mathrm{~mm} / \mathrm{a}: 58.4 \%)$. The rapid urbanization of Hanoi coupled with impervious pavements of developing areas and combined with extensive groundwater withdrawal as sole source for drinking water led to drawdown and land subsidence. Additionally, weaknesses within the internal administration and the lacking awareness of the future problems prevented to date the implementation of adequate methods and technologies.

\section{Tools for Groundwater Recharge}

Artificial groundwater recharge is worldwide a common measure to secure an increase of groundwater levels. It is often combined with natural attenuation measurements i.e. a soil passage of wastewater effluents [18-20]. The elected techniques depend from the origin of the used water and comply mainly with the climatic conditions i.e. the average precipitation. Cheap treatment of wastewater

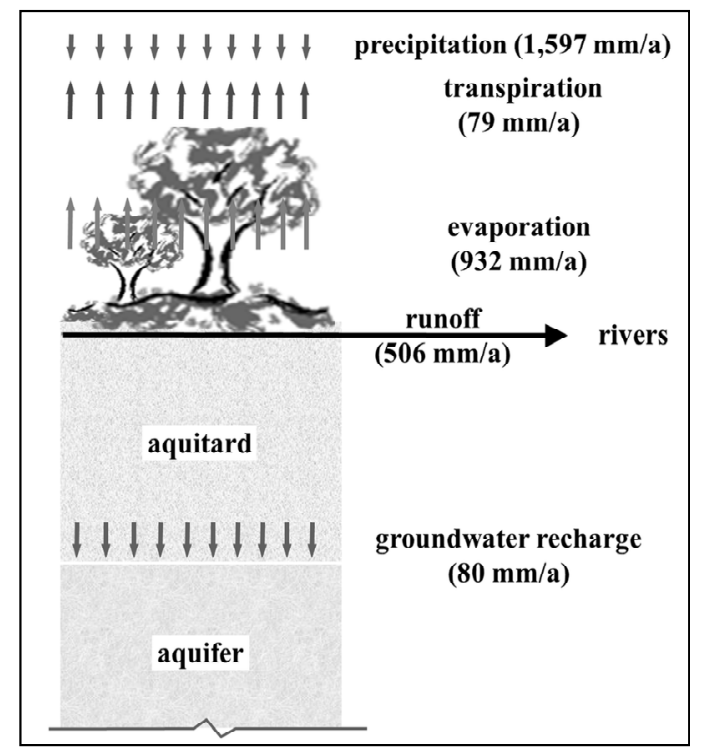

Figure 4. Water balance in Hanoi (Hoc, 2009). 
by infiltration into the vadose zone with groundwater reclamation as a positive secondary effect is usually made in arid regions like Israel [21]. Fresh water (rain) for groundwater enrichment is preferred in wet regions like India [22]. Rainwater harvesting can be managed by many methods e.g. by using cisterns or settling tanks.

These measurements can be combined with cleaning systems e.g. constructed wetlands. An important question is in each case the kind of infiltration of the treated or untreated water. Table 2 shows advantages and disadvantages of several infiltration scenarios. A sustainable technique has to ensure that fecal coliforms are not detectable or below certain limits. However, very small values $(<1)$ of fecal coliform concentrations are only possible after a lateral movement of about $100 \mathrm{~m}$ through the aquifer [24] (Table 3).

The optimum solution would be a technique which handles water from different sources e.g. from rain and wastewater. At present all solutions are only theoretically feasible and a transformation into real changes seems to be unlikely. The reason for that is not only the expenditure. Due to the heavy rainfalls in Vietnam the resource "water" is unappreciated and the strategy against growing water demands is still the exploitation of the groundwater. A rethinking of the people is necessary and it must be achieved upon a political way. Only in the long term it is feasible that the taxation system could be renewed and taxation revenue could support the construction and maintenance of sewage and drainage infrastructure [9].

\section{Conclusions}

The capital Hanoi has falling groundwater levels and subsequent damages like land subsidence. The lack of water is enforced by the fact that surface sealings prevent the heavy rainfalls during summer time from reaching the groundwater. The frequent floods during the rainy season are also amplified by that. First efforts have been made to find sustainable solutions which take into account the fast growing need of areas. It is essential that quality of reclaimed wastewater has to fulfill certain health standards. Experiences from other wastewater reclamation systems show that quality of the reclaimed water is not the problem at all. However, all these efforts are made without enough revenue for a complete renovation of the wastewater systems. A solution of the problem could be a certain tax which should be allocated to sewage, drainage and wastewater treatment in Hanoi. However, this is a question where the answer lies in the social and governmental levels.

Table 2. Comparison of selected recharge scenarios.

\begin{tabular}{|c|c|c|c|}
\hline Criteria & Recharge ponds & Shaft wells & Infiltrations wells \\
\hline $\begin{array}{l}\text { Hydrogeological condi- } \\
\text { tions }\end{array}$ & $\begin{array}{l}- \\
\text { possible only in shallow } \\
\text { impermeable layers }\end{array}$ & $\begin{array}{c}++ \\
\text { suitable in some districts }\end{array}$ & $\begin{array}{l}++ \\
\text { recharge of confined and } \\
\text { unconfined aquifers }\end{array}$ \\
\hline Land use & $\begin{array}{c}- \\
\text { large parcels needed } \\
\text { mostly in green areas }\end{array}$ & $\begin{array}{l}+ \\
\text { less area than recharge } \\
\text { ponds }\end{array}$ & $\begin{array}{c}++ \\
\text { less land use } \\
\text { also inhabited zones }\end{array}$ \\
\hline Costs & $\begin{array}{c}++ \\
\text { using existing ponds }\end{array}$ & $\begin{array}{c}+ \\
\text { can be dug manually }\end{array}$ & $\frac{-}{\text { high drilling costs }}$ \\
\hline Infiltration water quality & $\begin{array}{c}++ \\
\text { clogging prevention by sand } \\
\text { layers }\end{array}$ & $\begin{array}{c}+ \\
\text { aquifer clogging to be } \\
\text { avoided }\end{array}$ & $\begin{array}{c}- \\
\text { higher quality of infiltration } \\
\text { water }\end{array}$ \\
\hline
\end{tabular}

Table 3. Cleaning efficiency of soil aquifer treatment (adapted from [24, 25]).

\begin{tabular}{|c|c|c|}
\hline Parameter & $\begin{array}{l}\text { Typical input } \\
\text { values }[\mathrm{mg} / \mathrm{l}]\end{array}$ & $\begin{array}{c}\text { Typical output } \\
\text { values [mg/l] }\end{array}$ \\
\hline $\begin{array}{l}\text { biological oxygen } \\
\text { demand (BOD) }\end{array}$ & 250 & $\leq 30$ \\
\hline $\begin{array}{l}\text { total suspended } \\
\text { solids (TSS) }\end{array}$ & 11 & $<1$ \\
\hline $\begin{array}{l}\text { total organic } \\
\text { carbon (TOC) }\end{array}$ & $>10$ & $<5$ \\
\hline total nitrogen $(\mathrm{TN})$ & 60 & $<10$ \\
\hline total phosphorous (TP) & 8 & $<1$ \\
\hline fecal coliforms (FC) & $\begin{array}{c}>10,000 \\
{[\mathrm{n} / 100 \mathrm{ml}]}\end{array}$ & $\begin{array}{c}<1-22 \\
{[\mathrm{n} / 100 \mathrm{ml}]}\end{array}$ \\
\hline
\end{tabular}




\section{Acknowledgements}

This paper was conducted as a part of the excellence initiative "International Water Alliance Saxony (IWAS)", Ref. No. 02WM1028. Additional support came from the Bundesministerium für Bildung und Forschung (BMBF, Germany; project no. 02WA1148 "Evaluation and enhancing ground water effluent recharge technology").

\section{REFERENCES}

[1] D. D'haeze, D. Raes, J. Deckers, T. A. Phong and H. V. Loi, "Groundwater Extraction for Irrigation of Coffea Canephora in Ea Tul Watershed, Vietnam-A Risk Evaluation," Agricultural Water Management, Vol. 73, No. 1, 2005, pp. 1-19.

[2] Q. Feng, G. Liu, L. Meng, E. Fu, H. Zhang and K. Zhang, "Land Subsidence Induced by Groundwater Extraction and Building Damage Level Assessment-A Case Study of Datun, China," Journal of China University of Mining and Technology, Vol. 18, No. 4, 2008, pp. 556-560.

[3] T. Kerh, Y. G. Hu and C. H. Wu, "Estimation of Consolidation Settlement Caused by Groundwater Drawdown Using Artificial Neural Networks," Advances in Engineering Software, Vol. 34, No. 9, 2003, pp. 559-568. doi:10.1016/S0965-9978(03)00053-X

[4] H. Furumai, "Rainwater and Reclaimed Wastewater for Sustainable Urban Water Use," Physics and Chemistry of the Earth, Vol. 33, No. 5, 2008, pp. 340-346.

[5] Department of Economic and Social Affairs, Population Division, "World Urbanization Prospects: The 2003 Revision," United Nations, New York, 2004.

[6] http://www.un.org/esa/population/publications/wup2003/ WUP2003Report.pdf.

[7] T. M. Thu and D. G. Fredlund, "Modelling Subsidence in the Hanoi City Area, Vietnam," Canadian Geotechnical Journal, Vol. 37, No. 3, 2000, pp. 621-637. doi:10.1139/t99-126

[8] M. Berg, P. T .K. Trang, C. Stengel, J. Buschmann, P. H. Viet, N. Van Dan, W. Giger and D. Stüben, "Hydrological and Sedimentary Controls Leading to Arsenic Contamination of Groundwater in the Hanoi Area, Vietnam: The Impact of Iron-Arsenic Ratios, Peat, River Bank Deposits, and Excessive Groundwater Abstraction," Chemical Geology, Vol. 249, No. 1-2, 2008, pp. 91-112.

[9] P. Werner, G. Röstel, L. Fuchs and C. Stefan (Eds.), "Integrated Water Resources Management in Vietnam. Handbook for a Sustainable Approach," Dresden, Germany, 2010.

[10] S. Fink, "The Sustainability of Toilets in Hanoi, Vietnam," International Journal of Economic Development, Vol. 3, No. 3, 2001.

[11] T. Q. Nguyen and D. C. Helm, "Land Subsidence Due to Groundwater Withdrawal in Hanoi,Vietnam," Proceedings of the Fifth International Symposium on Land Subsidence, Hague, October 1995.
[12] HCA "Monitoring Results of 10 Monitoring Stations about Land Subsidence Caused on Sinking Groundwater Level in Hanoi from 2003 to 2008," Hanoi Construction Agency, Institute of Technology and Construction Industry, Hanoi, 2007.

[13] The Social Republic of Vietnam, Hanoi People's Committee and The Republic of Finland, Finnish International Development Agency FINNIDA: Hanoi, Vietnam, "Water Master Plan of Hanoi City for the Period of 1993-2010," Vol. 1, 1993.

[14] J. M. Trafford, A. R. Lawrence, D. M. J. Macdonald, V. D. Nguyen, D. N. Tran and T. H. Nguyen, "The Effect of Urbanisation on the Groundwater Quality beneath the City of Hanoi, Vietnam," BGS Technical Report WC/96/22, British Geological Survey, Keyworth, UK, 1996.

[15] F. Larsen, N. Q. Pham, N. D. Dang, D. Postma, S. Jessen, V. H. Pham, T. B. Nguyen, H. D. Trieu, L. T. Tran, H. Nguyen, J. Chambon, H. V. Nguyen, D. H. Ha, N. T. Hue, M. T. Duc and J. C. Refsgaard, "Controlling Geological and Hydrogeological Processes in an Arsenic Contaminated Aquifer on the Red River Flood Plain, Vietnam," Applied Geochemistry, Vol. 23, No. 11, 2008, pp. 3099-3115. doi:10.1016/j.apgeochem.2008.06.014

[16] E. J. M. Hensen, and B. Smit, "Why Clays Swell," The Journal of Physical Chemistry B, Vol. 106, No. 49, 2002, pp. 12664-12667. doi:10.1021/jp0264883

[17] B. Hoc, Vietnam Association of Hydrogeology, Hanoi, Vietnam, Personal Communication, 2009.

[18] E. Eiche, T. Neumann, M. Berg, B. Weinman, A. van Geen, S. Norra, Z. Berner, P. T. K. Trang, P. H. Viet and D. Stüben, "Geochemical Processes Underlying a Sharp Contrast in Groundwater Arsenic Concentrations in a Village on the Red River Delta, Vietnam," Applied Geochemistry, Vol. 23, No. 11, 2008, pp. 3143-3154. doi:10.1016/j.apgeochem.2008.06.023

[19] S. K. Sharma, C. M. Harun and G. Amy, "Framework for Assessment of Performance of Soil Aquifer Treatment Systems," Water Science and Technology: A Journal of the International Association on Water Pollution Research, Vol. 57, No. 6, 2008, pp. 941-946.

[20] T. Asano and J. A. Cotruvo, "Groundwater Recharge with Reclaimed Municipal Wastewater: Health and Regulatory Considerations," Water Research, Vol. 38, No. 8, 2004, pp. 1941-1951. doi:10.1016/j.watres.2004.01.023

[21] K. M. Hiscock and T. Grischek, "Attenuation of Groundwater Pollution by Bank Filtration," Journal of Hydrology, Vol. 266, No. 3-4, 2002, pp. 139-144. doi:10.1016/S0022-1694(02)00158-0

[22] H. Abbo and I. Gev, "Numerical Model as a Predictive Analysis Tool for Rehabilitation and Conservation of the Israeli Coastal Aquifer: Example of the SHAFDAN Sewage Reclamation Project," Desalination, Vol. 226, No. 1-3, 2008, pp. 47-55. doi:10.1016/j.desal.2007.01.233

[23] C. J. Glendenning and R. W. Vervoort, "Hydrological Impacts of Rainwater Harvesting (RWH) in a Case Study Catchment: The Arvari River, Rajasthan, India: Part 2. 
Catchment-Scale Impacts," Agricultural Water Management, Vol. 98, No. 4, 2011, pp. 715-730.

doi:10.1016/j.agwat.2010.11.010

[24] D. R. Kim, M. Ali, V. D. Thiem, J. Park, L. von Seidlein and J. Clemens, "Geographic Analysis of Shigellosis in Vietnam," Health \& Place, Vol. 14, No. 4, 2008, pp. 755-767. doi:10.1016/j.healthplace.2007.12.003
[25] H. Bouwer, "Ground Water Recharge with Sewage Effluent," Water Science \& Technology, Vol. 23, 1991, pp. 2099-2108.

[26] H. Bouwer, "Artificial Recharge of Groundwater: Hydrogeology and Engineering," Hydrogeology Journal, Vol. 10, 2002, pp. 121-142. 